\title{
昼光照明の簡易エネルギー評価手法の開発 \\ A SIMPLIFIED METHOD FOR ESTIMATING THE REDUCTION IN ANNUAL ELECTRIC POWER CONSUMPTION FOR LIGHTING DUE TO DAYLIGHTING
}

\author{
山田浩嗣*, 宿谷昌則** \\ Hirotsugu YAMADA and Masanori SHUKUYA
}

\begin{abstract}
This paper describes a method for estimating the decrease in annual electric power consumption for lighting due to daylighting. The proposed method is to use a chart for calculating annual mean daylight illuminance in a given room space and then to estimate the annual electric power consumption for lighting. The parameters included in the chart are window size, window orientation, room reflectance, and window types.

Annual electric power consumptions estimated using the proposed chart were found in good agreement with those calculated by detailed computer simulation.
\end{abstract}

\section{ke yword : daylighting, electric lighting, energy} 昼光照明、電灯照明、エネルギー

\section{1.はじめに}

直射日光の入射する日除けのある空からの室内昼光 照度の計算を可能にするために、直射日光率の理論が 提案され、その妥当性が実測や数值解析により検証さ れてきだ。この計算法を用いた昼光照明のエネルギ 一評価によると、空から得られる昼光の適切な導入に よって照明用電力消費量の大幅な削減が期待できる2)。 このような照明用電力消費量の解析には、照明計算に 関する専門知識だけでなく計算機に関するそれも不可 欠である。これらのことは、建築計画の特に初期段階 における昼光照明の検討を困難にしている。建築照明 計画といえば暗に電灯照明のみの計画を指し、昼光照 明の計画は無視されることが多いが、そのような状況 をいくらかでも改善するためには、建築計画の初期段 階で利用し得る、昼光照明の簡易エネルギー評価手法 の開発が必要である。本研究はその開発を目的とした。

\section{2.室内冝光照度簡易計算手法}

年間の照明用電力消費量は室内昼光照度と電灯照明 の方式によって決定される。そこではじめに室内平均 昼光照度を算出する方法を開発した。室内昼光照度は 空面の大きさ・方位・室内平均反射率 - 日除けの光学 的性質により算出される値であるので、本研究ではこ れらパラメータの違いから室内平均昼光照度を求める ための図表を作成した。なお、本研究では1日の最大 照度の年平均值が図表から算出できるようにした。

日最大窒内昼光照度の年平均值を算出するための図 表の作成には、平均的な大・中・小規模の事務室 ${ }^{3)}$ 対象として、表 1 に示した条件について室内昼光照度 シミュレーションを行い》、その結果を解析・統合す ることにより、地域毎の図表を作成することにした。 地域は東京・札棍・鹿児島を対象としたが、ここでは 東京の場合について説明する。

本論文は，参考文献8)で報告したものを修正・加筆したものである。

* 東洋建設, 修士 (工学) (当時, 武蔵工業大学 TOYO Construction Co., Ltd., M. Eng. 大学院)

** 武蔵工業大学工学部建築学科 教授·工博

Prof., Dept. of Architecture, Musashi Institute of Technology, Dr. Eng. 
図1は解析結果の一例である。この図はブラインド スラット角度の違いにより、どれだけ室内昼光照度に 変化が現われるかを示しており、表 1 の条件の組み合 わせによる約4000通りの計算結果を条件の違いごとに プロットしたものである。それぞれ回帰直線を最小 2 乗法を使って求めた結果が日最大室内昼光照度の年平 均值を算出するための図表の一部となる。このような 手続きを他のパラメータについても行い、それを統合 して1つの計算図表を完成する。

図2は以上の方法に基づいて作成した日最大室内昼 光照度の年平均值を算出するための図表例である。こ の計算図表例からは、水平ブラインド内付け片側採光 悹による東京における日最大室内昼光照度の年平均値 が算出できる。

計算手順は、図 2 の右下、経路図の太線矢印の示す とおりである。まず、左上の空面と計算対象点の位置 関係を表わす形態保数（立体角投射率）と室内昼光照 度の関係を示す図から始まり、順に計算図表中に与え られた条件をなぞることにより、最終的に求めたい日 最大室内昼光照度の年平均値を得る。

例えば、間口 $8 \mathrm{~m}$ 、室奥 $8 \mathrm{~m}$ 、天井高 $2.6 \mathrm{~m}$ 、空面積 $10.2 \mathrm{~m}^{2}(6.0 \mathrm{~m} \times 1.7 \mathrm{~m})$ の室において、空面中央から $2 \mathrm{~m}$ 離れた地点における疍光照度を表 2 に示した条件によ り計算する場合、まず空面の形態係数を文献 4）等に
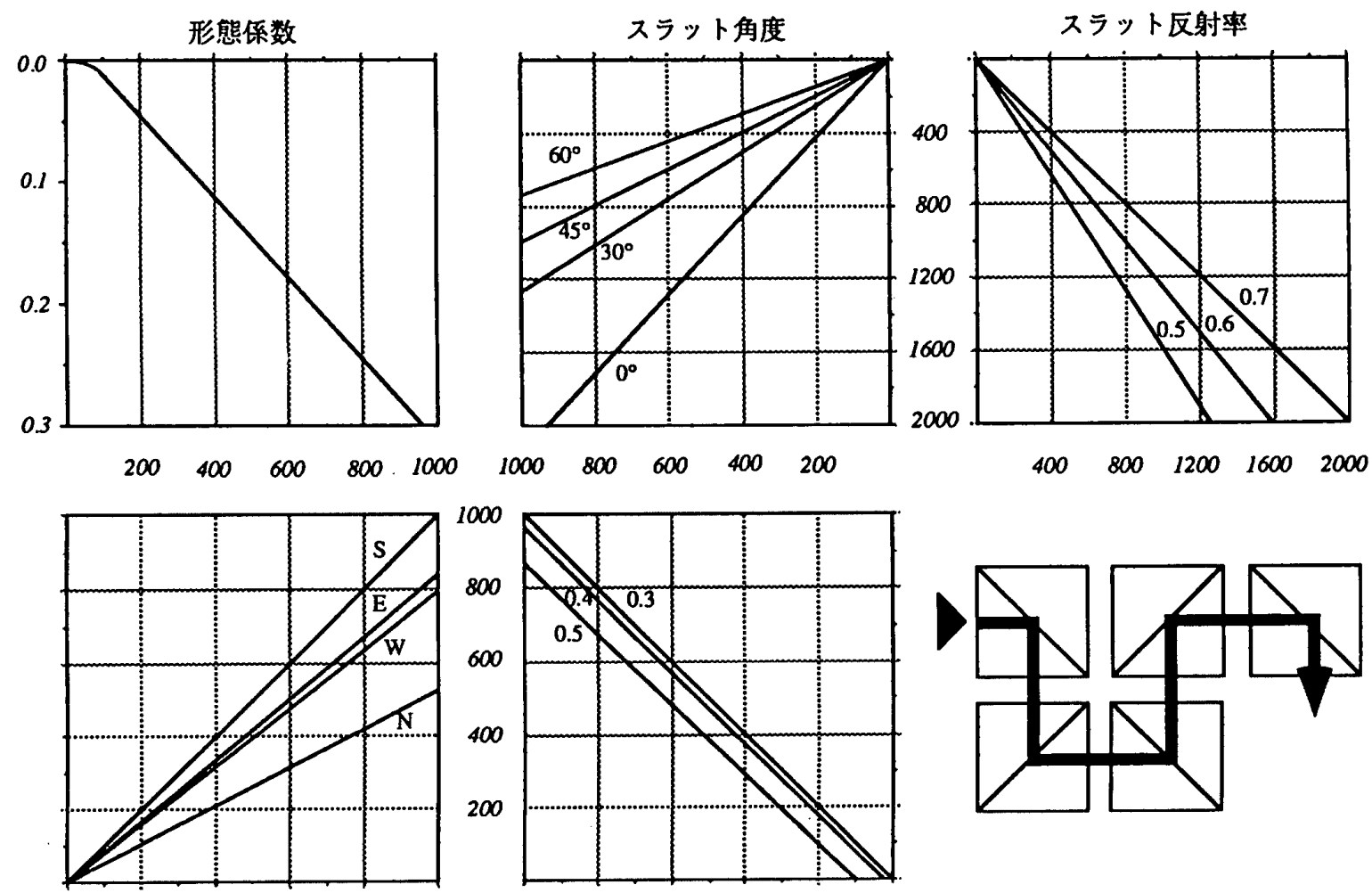

空面方位
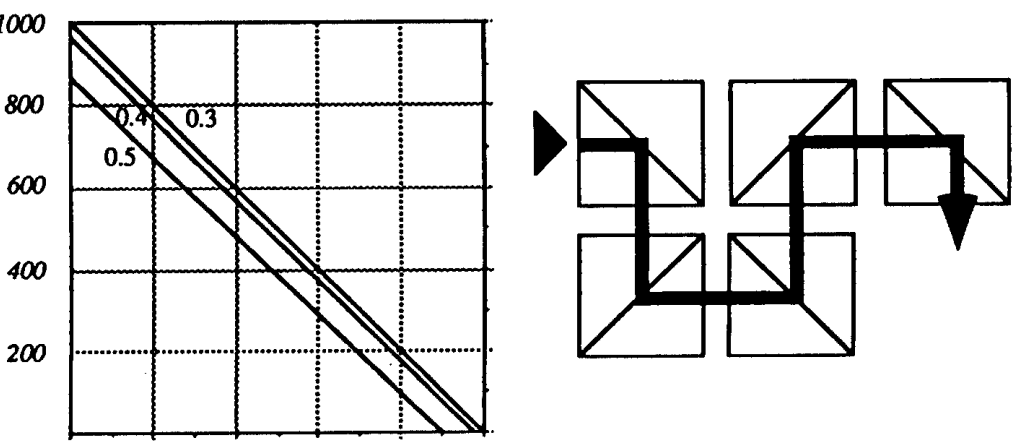

室内平均反射率

(東京、水平ブラインド内付け、片側採光空における日最大室内冒光照度の年平均值)

図 2 計算図表

表 1 シミュレーションの条件

\begin{tabular}{|c|c|}
\hline 形息係数 & $0.0 \sim 0.3$ \\
\hline 荌面方位 & 東·西·南·北 \\
\hline 室内平均反射率 & $0.3,0.4,0.5$ \\
\hline 日除け & $\begin{array}{l}\text { 水平ブラインド内付け } \\
\text { スラット角度 } 0^{\circ} 、 30^{\circ} 、 45^{\circ} 、 60^{\circ} \\
\text { スラット反射率 } 0.5 、 0.6 、 0.7\end{array}$ \\
\hline
\end{tabular}

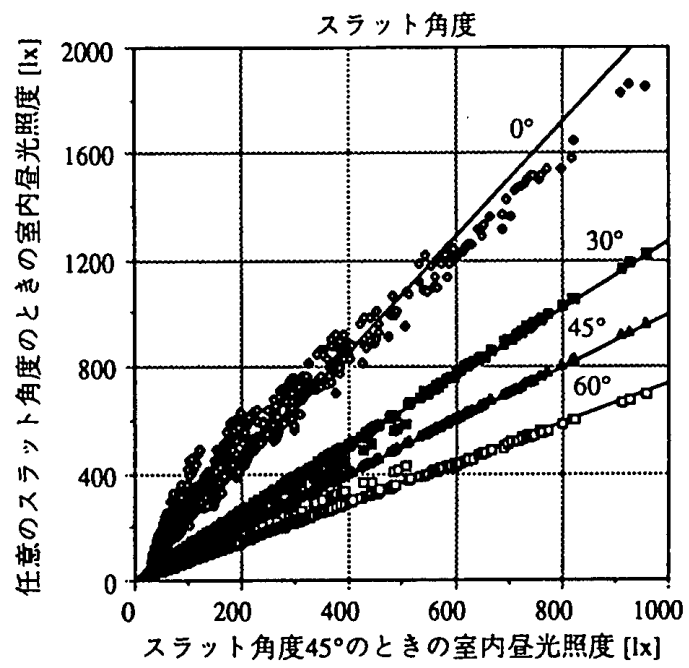

図 1 解析結果例 


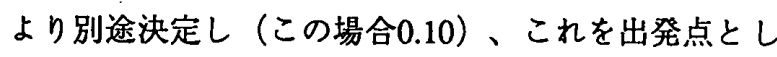
て室内昼光照度の日最大年平均值は的4001xを得る。 また、南向きの空を北向きに変更したとすると、室内 昼光照度の日最大年平均值が約 $1501 \mathrm{x}$ 下がって、2501x となることが直ちに読み取れる。このような計算条件 の変更による照度の変化が簡単に読み取れることが本 図表の利点と考える。

図 2 から空面に近づくほど（形態保数が大きくなる ほど）、南向きの空になるほど、室内平均反射率が上 がるほど、ブラインドスラット角度が小さくなるほど、 スラット反射率が上がるほど室内昼光照度は大きくな ることが分かる。

図 2 を使った室内冝光照度の推定の妥当性を確認す るために、精算値との比較を行った。図 3 がその結果 である。計算条件には形態保数・空面方位・スラット 角度などについて250の組み合わせについて検討した。 ただし、形態係数などは表 1 に示した範囲内の值とし

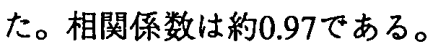

な㧍、本研究における精算値とは、宿谷らによって 文献 5）において提案された直射日光率・天空光率 . 地表面反射率による室内昼光照度計算理論に基づき、 計算された値をいう。またこの理論の妥当性は文献 6） 等によって検証されている。

\section{3.照明用消費電力量簡易計算手法}

図 4 のプロットはある室における年平均照度の経時 変化の一例である。これを 2 次曲線で近似したものが 実線である。この 2 次曲線は時刻を $t[\mathrm{~h}]$ 、室内昼光照 度の年平均値を $E[\mathrm{~lx}]$ として、

$$
E=-a\left(t-t_{0}\right)^{2}+E_{\max }
$$

ここて

$E_{\text {max }}$ : 日最大室内昼光照度の年平均值 $[\mathrm{x}]$;

$t_{0}$ : 日最大室内昼光照度の年平均值が 生じる時刻 [h]。

この（1）式を応用して、2 段階調光および連続調 光方式》による照明用電力消費量の計算方法を開発す ることにした。電灯照明への投入電力量は室内昼光照 度と設計照度 $E_{0}$ との大小関係により決まる。そこで、 日最大室内登光照度の年平均値 $E_{\text {max }}$ と $E_{0}$ の大小関係 によって2つに場合分けして電力消費量を求めること にした。なお、簡単のため、 $t_{0}$ は必ず室使用時間带の 中心（例えば、室使用時間带が 9:00-17:00であれば、 $t_{0}=13$ ）に生じると仮定した。

\section{i） $E_{\max } \geqq E_{0}$ の場合}

図 5 は 1 日の室内登光照度変動近似曲線とこの变動 に応じて照明器具に投入される電力量を模式的に示し
表 2 計算条件

\begin{tabular}{c|c}
\hline 計萛地点 & 空面から $2 \mathrm{~m}(0.10)$ \\
\hline 空面の方位 & 南面 \\
\hline 室内反射率 & 天井 0.7 \\
& 壁 0.5 \\
& 床 0.1 \\
& 面積加重平均 0.44 \\
\hline 日除け & 水平フラインド (内付け) \\
& スラット傾斜角 $45^{\circ}$ \\
& スラット反射象 0.7 \\
\hline
\end{tabular}

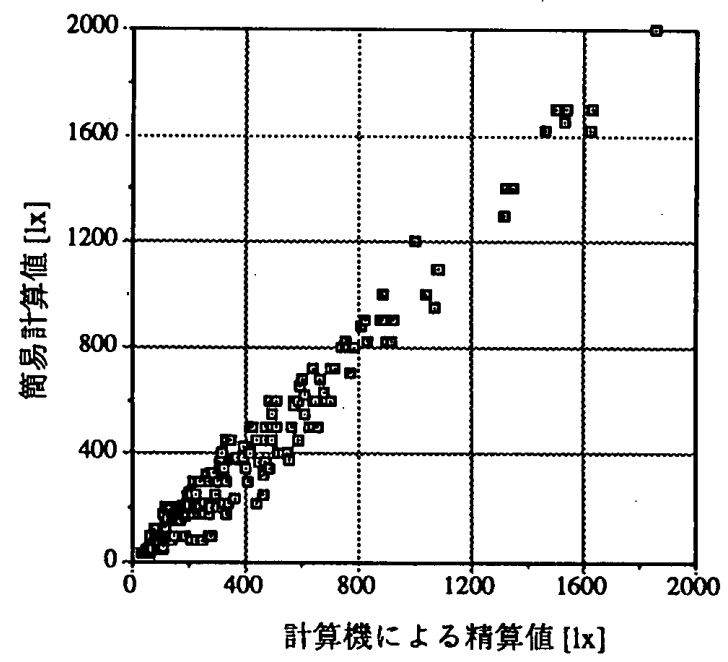

図 3 室内冝光照度の推定值と精算值との関係

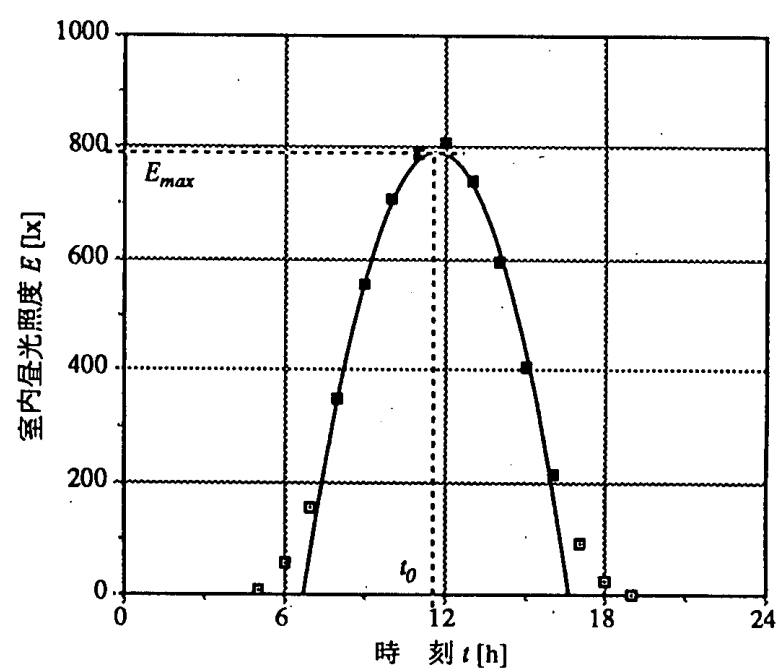

図 4 室内冝光照度变動の近似 
たものである。最大室内昼光照度の年平均值 $E_{\text {max }}$ が $E_{0}$ よりも大きいということは、室内の照度は昼光の みでまかなうことができる時間帯 $T$ をもつというこ とである。

2 段階調光方式の場合、横軸を時間 $t$ 、絴軸に照明 器具への投入電力とすると、1 日における照明器具へ の投入電力量は、図中の影をつけて示した長方形の面 積となる。

一方、連続調光方式の場合、室内昼光照度の変動に 応じて、図中の三角形の面積で表されるように投入電 力が制御されると仮定すれば、連続調光方式の投入電 力消費量は 2 段階調光方式の場合の $1 / 2$ となる。

図 5 を参考にして、2段階調光方式による1日の消 灯時間 $T$ は $t_{1}-t_{2}$ となる。 $t_{1} 、 t_{2}$ はともに設計照度 $E_{0}$ が昼光のみで満たせる時刻を表わし、 $E_{0}$ が (1) 式 のEで与えられるとすれば、 $T$ は次式で表すことがで きる。

$$
T=t_{1}-t_{2}=2 \sqrt{\frac{E_{\max }-E_{0}}{a}}
$$

近似 2 次曲線（1）式における係数 $a$ は 2 節に述 べた計算機による解析結果によると、日最大室内昼光 照度の年平均値 $E_{\text {max }}$ と線形的な関係にある。一例を 図6に示す。これは水平ブラインド内付けで東京の場 合である。図6の関係を2.で示した計算図表と組み 合わせれば、日最大室内昼光照度の年平均値 $E_{\text {max }}$ を 算出し、さらに係数 aを求めることができることにな る。

例えば、2.に示した計算例では $E_{\text {max }}$ は4001xであっ たので、係数 $a$ は図 6 から15となる。設計照度を $3001 x$ とすると、1 日の消灯時間は（2）式から約 5 時間と計算される。

2 段階調光方式の場合の年間照明用電力消費量 $A_{E}$ は、電灯照明の投入電力 $K_{\text {W }}$ 与条件とすれば以下の ように表せる。

$$
A_{E}=K_{W} \times\left(T_{0}-T\right) \times D
$$

ここで

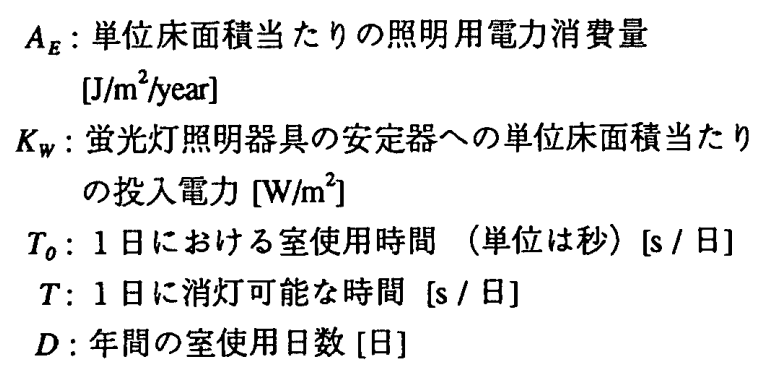

式（3）で $\left(T_{0}-T\right)$ が負となる場合があるが、これは 1 日の室使用時間より昼光のみで設計照度を満たせる 時間のほうが長いことを意味する。

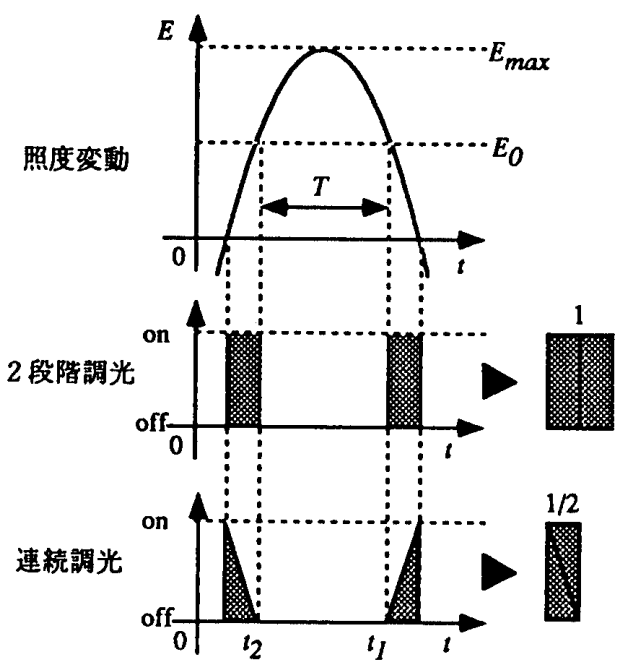

图 5 冝光照度の変動と電力消費パターンの モデル化 $\left(E_{\max } \geqq E_{0}\right)$

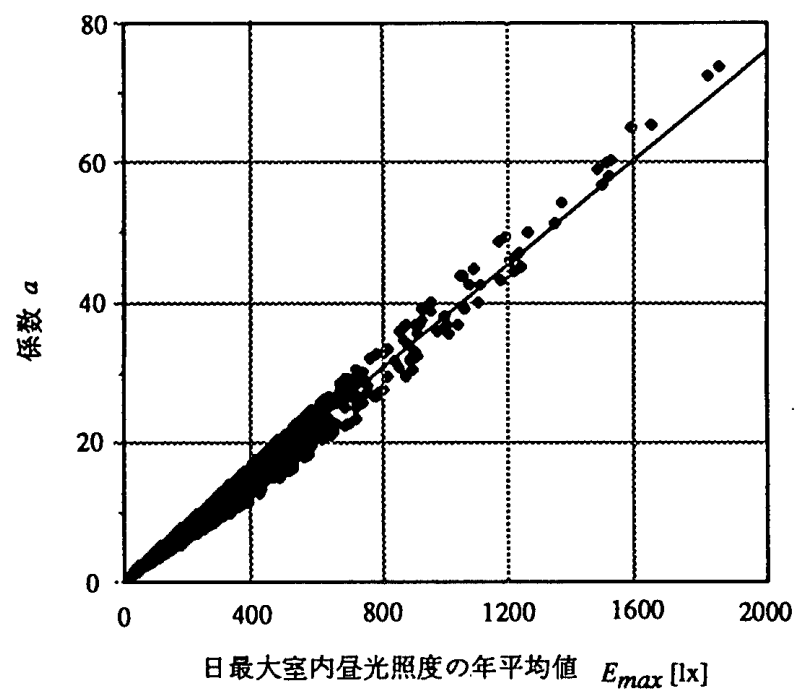

图 $6 E_{\max }$ と係数 $a$ の関係

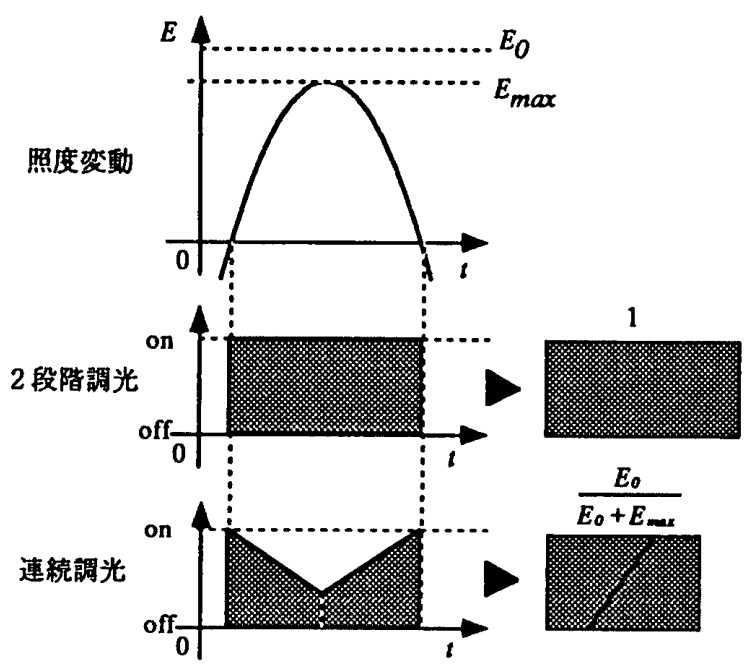

図 7 冝光照度の变動と電力消費バターンの モデル化 $\left(E_{\max }<E_{0}\right)$ 
したがって $\left(T_{0}-T\right)<0$ のと $\left(T_{0}-T\right)=0$ とする。

一方、連続調光方式にお打る年間照明用電力消費量 $A_{E}{ }^{\prime}$ は以下のように表すことにする。

$$
A_{E}^{\prime}=k \times A_{E}
$$

前述のように、 $T_{o}$ が $t_{0}$ を中心とした時間帯であると 仮定したので $k$ は $1 / 2$ となる。

\section{ii) $E_{\max }<E_{0}$ の場合}

図 7 は、図 5 と同樣に 1 日の室内昼光照度変動とそ のときの照明器具に投入される電力量を模式的に示し たものである。2 段階調光方式の場合、室内昼光照度 が設計照度 $E_{0} に 1$ 日中満たないため、営光灯は䅂日 点灯となり、 $T=0$ となる。照明器具への投入電力は 図中の影をつけて示した長方形の面積となる。

一方、連続調光方式の場合には室内昼光照度は設計 照度に満たない場合でも、設計照度が満たされるよう に昼光照度に応じて調光を行い、図 7 中の連続調光の 場合の影をつけて示した面積のように1日の投入電力 量を変化させるものとする。この面積は 2 段階調光方 式における 1 日の投入電力量を 1 として $E_{0} /\left(E_{0}+E_{\text {max }}\right)$ で表すことにする。

2 段階調光方式の場合の年間照明用電力消費量 $A_{E}$ は、

$$
A_{E}=K_{W} \times T_{0} \times D
$$

一方、連続調光方式の年間照明用電力消費量 $A_{E}$ 'は

$$
\begin{aligned}
& A_{E}{ }^{\prime}=k \times A_{E} \\
& k=\frac{E_{0}}{E_{0}+E_{\max }}
\end{aligned}
$$

係数 $k$ と $E_{\text {max }}$ の関係を、i) とii)の双方の場合に ついてまとめて図8に示す。

以上に示した照明用電力消費量の計算手法の妥当性 を確認するために、照明用電力消費量の計算機による 精算值との比較を行った。図 9 は 2 段階調光方式の場 合の精算值と簡易計算值の相関を示したものである。 計算条件は図 2 が適用できる60条件とした。相関係数 は0.92であり、十分な精度であると考えられる。

この計算手法の信頼区間を明らかにするために、精 算値と簡易計算値の残差の分析を行った。図10は残差 の度数分布である。残差の平均值は $0.2 、$ 標準偏差は 9.5であった。図10の残差分布を正規分布とみなすと、 照明用電力消費量の推定値 $A_{E}$ の95\%信頼区間は $A_{E}$ $\pm 20 \mathrm{MJ} / \mathrm{m}^{2} / \mathrm{year}$ となる。なお立却される $5 \%$ はスラッ 卜角度が $0^{\circ}$ で室奥行は $3 \mathrm{~m}$ しかないような条件であ ることが分かった。

連続調光方式についても同様の比較検討を行った結

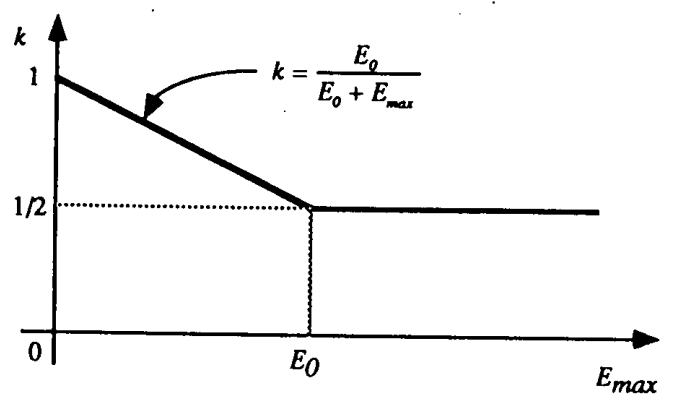

図 $8 E_{\max }$ と係数 $k$ の関係

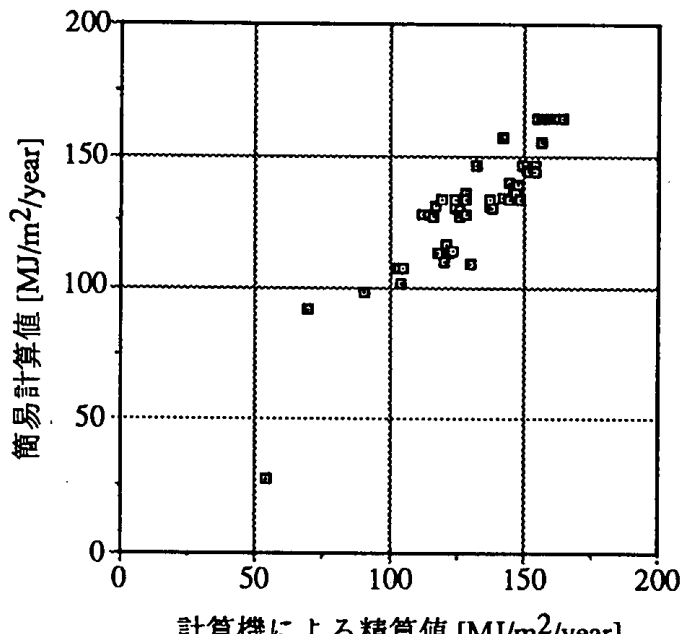

图 9 年間照明用電力消費量の簡易計算值と 精算值との比較（2 段階調光方式）

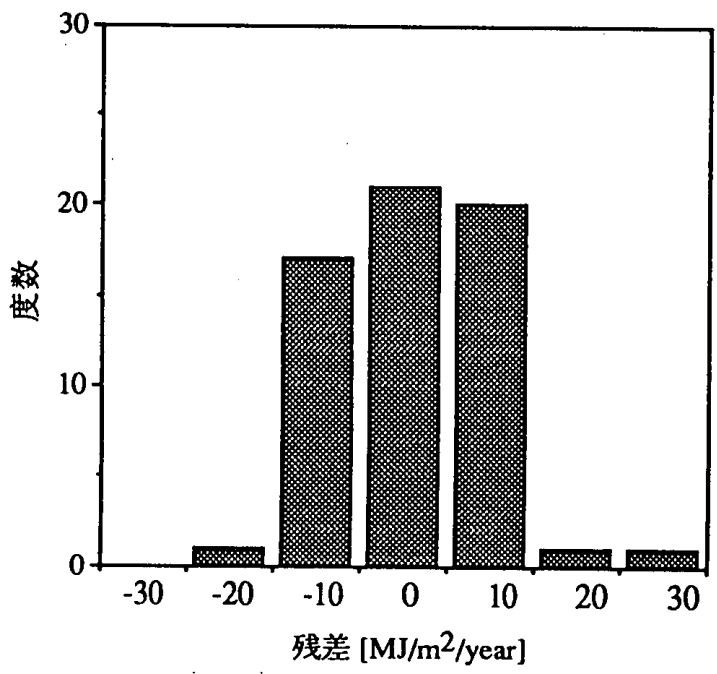

図10 年間照明用電力消費量の簡易計算值と 精算値の残差の度数分布（2 段階調光方式） 
果をそれぞれ図11、図12に示す。精算值と簡易計算値 の相関係数は 0.80 、残差の平均値は-4.3、標準偏差は 13.4となった。図12から残差の中央值が約 $-10 \mathrm{MJ} / \mathrm{m}^{2} /$ yearずれることがわかる。これは、電力消費 量の推定值が計算機による精算值よりも全体的に常に 約 $10 \mathrm{MJ} / \mathrm{m}^{2} / \mathrm{year}$ 大きめになる傾向がみられることを示 している。この傾向は、簡易計算法が精算法に対して もつ偶然誤差ではなく、系統誤差である。

\section{4.まとめ}

昼光照明の簡易エネルギー評価の計算手法の開発を 行った。その結果、

1）1日の最大室内昼光照度の年平均値を空面方位 · 室内平均反射率・空システムの種類等の関数とし て表し、これを図表としてまとめることができた。

2) 室内昼光照度の経時変化を 2 次関数として表現し、 関数の中に現われる定数を日最大室内昼光照度の 年平均値と関係づけることができた。

3）1）と 2) の結果を総合して、年間照明用電力消 費量を予測する計算手法を開発した。

4）簡易計算手法の適用範囲と信頼性を確認するため に計算機による年間照明用電力消費量の精算值と の比較により検証を行った。東京で空面に水平ブ ラインド内付けがあって、2段階調光方式の場合 の年間照明用電力消費量の推定値は、95\%信頼確 率で $\pm 20 \mathrm{MJ} / \mathrm{m}^{2} / \mathrm{year}$ 以下の誤差で予測可能である ことが明らかになった。また、東京で空面に水平 ブラインド内付けがあって、連続調光方式の場合 の電力消費量の推定値は、計算機による精算値よ $\eta も$ 全体的に約 $10 \mathrm{MJ} / \mathrm{m}^{2} / \mathrm{year}$ 大きめになる傾向が 見られた。

以上のことから、本研究で開発した簡易計算手法は、 2 段階調光方式の場合には、十分な精度を有している と考えられる。また、連続調光方式の場合にあっても、 上述の系統誤差を考慮するならば、十分に使用可能と 考えられる。

\section{【参考文献】}

1) 宿谷昌則：光と熟の建築環境学、丸善、1993, pp.129-159.

2) 宿谷昌則：建筑環境学 1 （木村建一編）、丸善、1992, pp.35-66.

3)梅田和彦、宿谷昌則：自然照明 - 自然換気と事務所建 築エネルギー消費に関する数值解析、日本建築学会大 会講演梗概集、1992,pp.1065-1066.

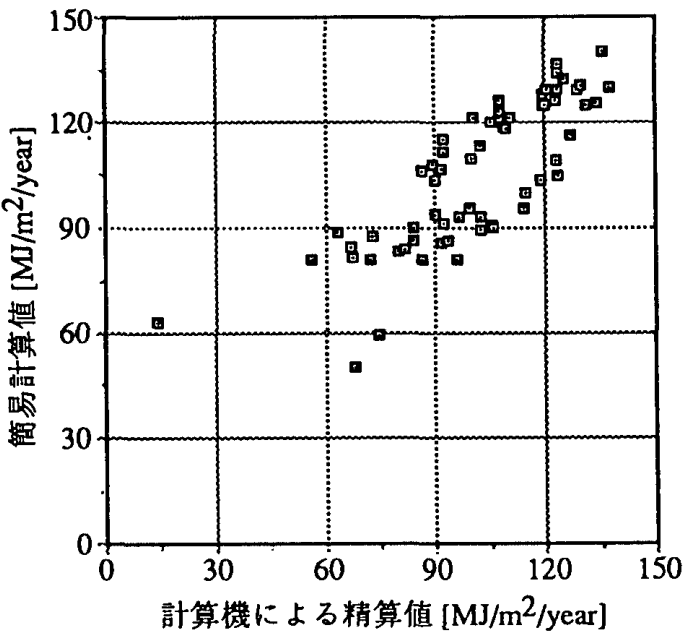

図11間照明用電力消費量の簡易計算值と 精算值との比較（連続調光方式）

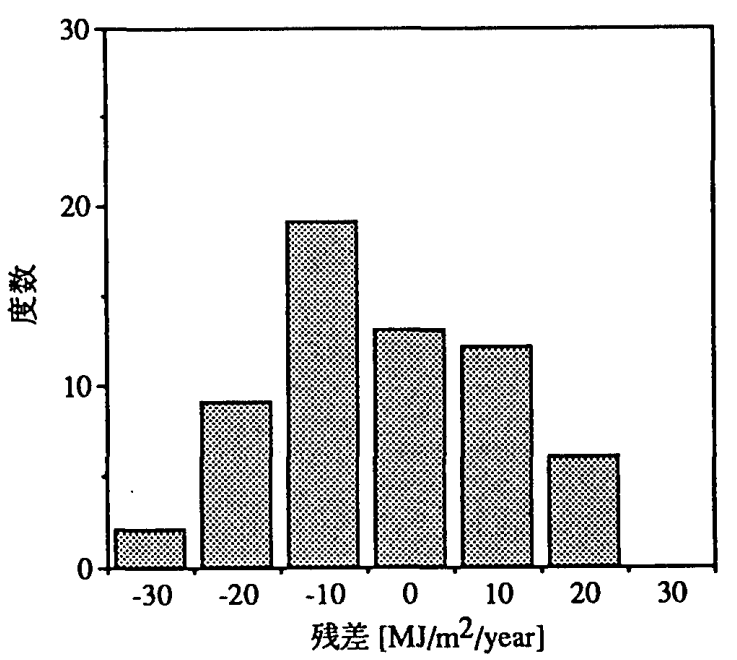

图12 年間照明用電力消費量の簡易計算俥と 精算值の残差の度数分布（連続調光方式）

4) 日本建築学会編：建築設計資料集成 1 㻴境、丸善、 1978,pp.81-82,pp.101.

5) 宿谷昌則、木村建一：反射ルーバーまたはベネシャンブ ラインドのある空からの直射日光を含む昼光による室内 照度の計算理論、日本建築学会論文報告集 第321号、 1982,pp.108-116.

6)八田次郎、野谷昌克、大橋清文、宿谷昌則：直射日光率 を用いた室内昼光照度計算法の実用性の検討、日本建築 学会大会講演梗概集、1991,pp.59-60.

7) 砂田竜男、宿谷昌則：昼光照明の省エネルギー効果に関 する数值解析、日本建築学会大会講演梗概集、1990, pp.785-786.

8）山田浩嗣、宿谷昌則：昼光照明の簡易エネルギー評価に 関する開発、日本建築学会大会講演梗概集、1995, pp.547-548.

（1995年 4 月 5 日原稿受理，1995年10月18日採用決定） 